\title{
UPAYA MENINGKATKAN HASIL BELAJAR PESERTA DIDIK MENGGUNAKAN MODEL CONTEXTUAL TEACHING AND LEARNING PADA PELAJARAN IPA
}

\author{
Mursilah \\ SDN 51/IX SETIRIS MUARO JAMBI \\ Email: silamur76@gmail.com
}

\begin{abstract}
The purpose of this research was to improve student learning outcomes using the contextual teaching and learning model (CTL), in natural science lessons on the sub-theme of plants as a source of life, design research of Classroom Action Research (CAR), two cycles and four stages each; plans, actions, observations and reflections. The research subject were class VI elementary school number 51/IX Setiris Muaro Jambi, consisting of 22 students. Data collection techniques used observation and formative tests, Data analysis used simple tabulation calculations, the success criteria are $\geq 73$ individually and $100 \%$ classical, the results showed that, learning success score $18 \%$ increased to $64 \%$ in the first cycle and increased again to $100 \%$ in the second cycle, with the highest score of 84 , the lowest score of 73 and an average score of 79.71, teacher observation by $70 \%$ increased to $88 \%$, student observation by $65 \%$ increased to $85 \%$. Therefore, it can be concluded that the CTL learning model can improve student learning outcomes in natural science on the sub-theme of plants as a source of life in class VI students of elementary school number 51 / IX Setiris Muaro Jambi district.
\end{abstract}

Keywords: learning outcomes, CTL learning model, natural sciences

\begin{abstract}
Abstrak
Tujuan penelitian untuk meningkatkan hasil belajar peserta didik menggunakan model pembelajaran Contextual Teaching and Learning (CTL) mata pelajaran IPA sub tema tumbuhan sumber kehidupan. Desain Penelitian Tindakan Kelas meliputi dua siklus masing-masing empat tahap; rencana, tindakan, pengamatan dan refleksi. Subjek penelitian kelas VI SDN 51/IX Setiris Muaro Jambi beranggotakan 22 peserta didik, Teknik pengumpulan data melalui observasi dan tes formatif. Analisis data menggunakan tabulasi dengan persentase senderhana, kriteria keberhasilan yaitu $\geq 73$ secara individu dan $100 \%$ klasikal. Hasil penelitian menunjukkan bahwa dari ketuntasan belajar $18 \%$ meningkat menjadi $64 \%$ pada siklus I dan kembali meningkat menjadi $100 \%$ pada siklus II dengan nilai tertinggi 84 , terendah 73 dan rata-rata skor 79,71 , lembar observasi guru dari $70 \%$ meningkat menjadi $88 \%$, observasi peserta didik dari $65 \%$ meningkat menjadi $85 \%$. Dengan demikian disimpulkan bahwa model pembelajaran CTL dapat meningkatkan hasil belajar IPA sub tema tumbuhan sumber kehidupan peserta didik kelas VI SDN 51/IX Setiris Muaro Jambi.
\end{abstract}

Kata Kunci: hasil belajar, model pembelajaran CTL, IPA 


\section{PENDAHULUAN}

Proses pembelajaran IPA dapat dilakukan dengan berbagai cara, metode, Teknik, dan pendekatan namun kenyataan dilapangan masih saja ditemukan proses pembelajaran tidak sesuai dengan harapan yang berujung rendahnya hasil belajar peserta didik. Fenomena tersebut sangat dekat dengan pemandangan ditempat peneliti bertugas, Rumusan kompetensi dalam K13 yang dipadu dan dikemas dalam bentuk tema yang diperinci kedalam sub tema tumbuhan sumber kehidupan yang didalamnya dipetakan pelajaran IPA, ternyata bukanlah hal yang mudah bagi peserta didik untuk mencapai tujuan pembelajaran yaitu agar peserta didik memiliki kemampuan menjelaskan dengan percaya diri tentang struktur tumbuhan dan perkembangbiakkan jenis generatifnya.

Berdasarkan studi pendahuluan yang dilakukan dengan pengamatan dan wawancara bersama beberapa peserta didik kelas VI SDN 51/IX Setiris Muaro Jambi yang juga merupakan kelas dimana peneliti sendiri menjadi guru kelasnya terungkap bahwa banyak peserta didik yang mengeluh terhadap materi IPA khususnya sub tema tumbuhan sumber kehidupan. Tema yang diaplikasikan pada awal semester I (Ganjil) tahun ajaran 2019/ 2020 tepatnya pada bulan ke 2 yaitu agustus 2019, terungkap bahwa sebagian peserta didik menganggap materi sulit untuk dicerna, sebagian menganggap pelajaran IPA bukan pelajaran yang menyenangkan, sebagian peserta didik merasa sulit dalam penerapan materinya baik sebagai anggota keluarga, masyarakat dan peserta didik di sekolah, kondisi tersebut semakin lengkap setelah akhirnya peneliti menemukan hasil ulangan harian peserta didik menunjukkan rata-rata skor sebesar 65 , 57\% dengan ketuntasan klasikal 18\% dengan kata lain dari 22 peserta didik hanya terdapat empat peserta didik yang tuntas sedangkan 18 lainya belum tuntas, fenomena kesenjangan yang terjadi menjadi umpan balik tersendiri bagi peneliti untuk mengambil langkah yang tepat dalam upaya memperbaiki proses dan hasil belajar disamping pembinaan kompetensi sebagai tenaga pendidik yang professional sehingga peserta didik dapat mencapai tujuan pembelajaran baik ouput maupun outcome.

Permendikbud No 53 tahun 2015 tentang penilaian hasil belajar Pasal 1 ayat (6) menyatakan kriteria ketuntasan minimal yang kemudian disingkat KKM 
ditetapkan oleh sekolah dengan memperhatikan kompetensi lulusan dan mempertimbangkan karakteristik peserta didik, karakteristik mata pelajaran dan kondisi sekolah.

Bertolak dari pernyataan di atas maka, yang dijadikan frekuensi ketuntasan belajar peserta didik yaitu KKM yang telah ditetapkan sekolah SDN 51/IX Setiris Muaro Jambi yaitu untuk pelajaran IPA kelas VI sebesar $\geq 73$ secara perorangan dengan ketuntasan klasikal 100\%. Setelah peneliti menempuh tahapan kajian literatur dalam upaya memperkaya khasanah pengetahuan sekaligus menemukan langkah yang tepat untuk merespon kesenjangan yang ada, peneliti temukan begitu banyak alternatif solusi yang ditawarkan para ahli ataupun researcher namun justru disinilah tantangan tersendiri bagi peneliti dalam memilih alternatif solusi yang tepat guna dan tepat sasaran yang cocok dan sesuai untuk diterapkan pada peserta didik peneliti, setelah menyocokkan dan melakukan penyesuaian, peneliti mempunyai dugaan kuat bahwa dengan memperbaiki proses pembelajaran lebih tepatnya menggunakan model pembelajaran Cotextual Teaching and learning yang kemudian disingkat CTL dapat meningkatkan hasil belajar peserta didik pelajaran IPA sub tema tumbuhan sumber kehidupan.

Pemilihan model pembelajaran CTL dianggap sangat sesuai dengan karakteristik pemetaan kompetensi dasar IPA yaitu bagaimana materi pelajaran dapat dihubungkan dengan kegiatan dan atau aktivitas sehari hari peserta didik, dimana penghubungan tersebut merupakan eksistensi model pembelajaran CTL, sejalan dengan itu penelitian berjenis penelitian Tindakan kelas (PTK) oleh Wulandari, L, A dan Koesdyantho (2018) dengan tujuan meningkatkan sikap peserta didik menggunakan strategi pembelajaran contextual teaching and learning (CTL), hasil penelitian menemukan bahwa penerapan strategi pembelajaran CTL dapat meningkatkan sikap peserta didik kelas V SDN Prawit 1 No. 69 Surakarta Tahun Pelajaran 2017/2018. Selanjutnya Sofiah, (2018) melakukan penelitian berjenis penelitian tindakan kelas yang dilaksanakan pada semester I tahun ajaran 2017/2018, dengan tujuan meningkatkan hasil belajar peserta didik pelajaran IPA kelas II, hasil penelitian menunjukkan bahwa model pembelajaran contextual teaching and learning (CTL) dapat meningkatkan 
hasil belajar peserta didik kelas II mata pelajaran IPA SDN 111/IX Muhajirin.

Tujuan penelitian untuk mengetahui model pembelajaran CTL dalam meningkatkan hasil belajar IPA sub tema tumbuhan sumber kehidupan pada peserta didik kelas VI SDN 51/IX Setiris Muaro Jambi.

Mulyasa (Daryanto, 2018: 141) mengemukakan pembelajaran kontekstual yang akrab dengan istilah contextual Teaching and learning (CTL) merupakan konsep pembelajaran yang penekanannya bagaimana keterkaitan materi pembelajaran yang diikuti dengan dunia kehidupan peserta didik secara nyata. Dengan strategi menghubungkan materi terhadap kegiatan nyata peserta didik kecenderungan peserta didik memahami pelajaran secara komprehenshif dengan sendirinya terbina sehingga tujuan pembelajaran sesuai harapan baik bagi guru maupun siswa sebagai outcome.

Lebih lanjut Alwasilah (Tukiran Tuniredja, dkk, 2017: 54) menyatakan bahwa terdapat tujuh ayat pendidikan kontekstual, yaitu: (1) problem yang menjadi basis dalam pembelajaran; (2) keberagaman konteks; (3) kebhinekaan peserta didik; (4) peserta didik yang senantiasa belajar mandiri; mendapatkan pembelajaran dengan kolaborasi; (6) penelitian autentik; dan (7) memiliki standar tinggi.

\section{METODE PENELITIAN}

Penelitian ini berjenis Penelitian Tindakan Kelas (PTK) sebagaimana Daryanto, (2018: 3) menyatakan bahwa penelitian Tindakan kelas (PTK) merupakan terjemahan dari Classroom Action Research yaitu suatu Action Research yang dilakukan oleh guru untuk memecahkan masalah pembelajaran di kelasnya. Pada setiap siklus menempuh empat tahapan yaitu rencana, Tindakan, observasi/ pengamatan dan refleksi, setiap siklus dilakukan dua kali pertemuan masingmasing pertemuan $3 \times 45$ menit, diakhir siklus diberikan tes formatif untuk mengukur keterandalan model CTL sekaligus melihat keberhasilan dan ketuntasan belajar peserta didik.

Lokasi penelitian yaitu SDN 51/IX Setiris Muaro Jambi tepatnya desa setiris kecamatan maro sebo kabupaten muaro jambi, dilakukan pada awal semester I (Ganjil) Tahun Ajaran 2019/ 2020 dengan subjek kelas VI beranggotakan 22 peserta didik yaitu 11 laki-laki dan 11 perempuan, Teknik pengumpulan data menggunakan lembar observasi skala 
likert $1-4$, aktivitas guru meliputi 10 item dan lembar observasi kegiatan peserta didik terdiri dari 10 item, dan soal tes formatif, pada prosesnya peneliti dibantu dua kolaborator penelitian sebagai pengamat/ observer yaitu satu orang kepala sekolah SDN 51/IX Setiris Muaro Jambi dan satu orang guru senior SDN 51/IX Setiri Muaro Jambi.

Adapun analisis data dilakukan dengan menganalisis perhitungan yang ditabulasi dalam bentuk persentase sederhana yaitu: untuk menganalisis hasil observasi menggunakan rumus:

Presentase nilai rata-rata

$$
(\mathrm{NR})=\frac{\text { Jumlah Skor }}{\text { Jumlah Maksimal }} \times 100 \%
$$

Sedangkan rumus yang digunakan untuk menentukan ketuntasan belajar peserta didik secara klasikal menggunakan rumus:

$\mathrm{KK}=\frac{N}{s t} x 100$

Keterangan:

KK : Ketuntasan klasikal

$\mathrm{N}$ : Jumlah peserta didik yang tuntas

ST : Jumlah peserta didik seluruhnya.

Hamdi, M (2018: 148)

Agar data yang dihimpun dari penjaringan Teknik pengumpulan data berupa lembar observasi dan ketuntasan belajar peserta didik dapat dimaknai dan diinterpretasikan maka, semua hasil yang diperoleh selanjutnya dikonversikan kedalam kategori seperti pada tabel 1

Tabel 1. Konversi Interpretasi Skor

\begin{tabular}{cc}
\hline Kategori $(\%)$ & Interpretasi \\
\hline $90-100$ & Sangat Tinggi \\
\hline $75-89,99$ & Tinggi \\
\hline $55-74,99$ & Cukup \\
\hline $30-54,00$ & Rendah \\
\hline 0 & Sangat Rendah \\
\hline
\end{tabular}

Kriteria keberhasilan yaitu:

Penelitian dikatakan berhasil manakala hasil belajar peserta didik secara individul mencapai skor $\geq 73$ dan ketuntasan klasikal 100\%

\section{HASIL DAN PEMBAHASAN}

Sebelum akhirnya peneliti melaksanakan tindakan, kegiatan di awali penjaringan pre test dengan tujuan untuk mengetahui kondisi awal yang kemudian disebut pra siklus, diketahui bahwa nilai terendah yaitu 60 , nilai tertinggi 73 , rata-rata skor 65,57 dan ketuntasan klasikal sebesar $18 \%$ atau masih terdapat $82 \%$ lainnya belum tuntas yang berada pada kategori sangat rendah.

\section{Siklus I}

\section{Perencanaan (Planning)}

Tahapan perencanaan disebut juga dengan tahapan merencanakan tindakan, Adapun kegiatan yang peneliti lakukan diantaranya: (1) melakukan perizinan kepada kepala sekolah 51/IX Setiri 
muaro jambi menyampaikan maksud peneliti yaitu ingin melakukan PTK di kelas peneliti sendiri sekaligus memohon berkenannya untuk menjadi pengamat/ observer/ kolaborator penelitian; (2) Mensolidkan dan menyesuaikan waktu pelaksanaan dengan kegiatan sekolah; (3) melakukan konsolidasi sekaligus memastikan satu orang guru senior SDN 51/IX Setiris muaro jambi berkenan menjadi pengamat/ observer/ kolaborator penelitian; (4) mempersiapkan skenario atau Langkah-langkah pembelajaran dengan melibatkan model pembelajaran CTL pada rencana pelaksanaan pembelajaran (RPP); (5) mempersiapkan alat pengumpulan data yaitu lembar observasi aktivitas guru, lembar observasi kegiatan peserta didik dan menyiapkan tes formatif;

Memastikan tegangan arus listrik dapat beroperasi dengan stabil. Item yang ditetapkan pada lembar observasi aktivitas guru dapat dilihat pada tabel 2

Tabel 2. Observasi Aktivitas Guru Aktivitas Guru

Menyampaikan tujuan pembelajaran Memotivasi peserta didik/merumuskan masalah

Mengaitkan dengan pelajaran berikutnya

Menyampaikan materi pelajaran yang dikorelasikan dengan aktivitas keseharian/ menyampaikan langkah-langkah dan metode pelajaran dengan model CTL

Menjelaskan materi yang dianggap sulit dikaitkan dengan aktivitas keseharian

\begin{tabular}{l}
\hline \multicolumn{2}{c}{ Aktivitas Guru } \\
\hline peserta didik \\
\hline Mendorong peserta didik mengaitkan \\
situasi/ keadaan di dunia nyata dengan \\
pelajaran yang tengah berlangsung \\
\hline Memicu peserta didik untuk saling \\
menunjang dalam kelompok \\
\hline Mengamati dan membimbing peserta didik \\
\hline Penguasaan kelas \\
\hline Manajemen waktu \\
\hline
\end{tabular}

Selanjutnya item observasi

kegiatan peserta didik dapat dilihat pada tabel 3

Tabel 3. Observasi Kegiatan Peserta Didik

Kegiatan peserta didik

Mendengarkan/ memperhatikan penjelasan guru

Pelajaran diterima dengan gembira

Kegigihan bertanya tentang pelajaran yang dihubungkan dengan aktivitas sehari hari peserta didik

Antusias merespon pelajaran yang berkaitan dengan aktivitas keseharian peserta didik

Memberikan contoh kongkrit aktivitas sehari-hari peserta didik yang berhubungan dan pelajaran

Keaktifan bekerjasama dengan intensif bersama anggota kelompok

Menyajikan hasil kelompok dengan percaya diri

Menerima masukan dari anggota kelompok dan kelompok lain

Menyimpulkan dan merangkum pelajaran Mengerjakan tes formatif

\section{Tindakan (Acting)}

Tahap tindakan merupakan tahapan lanjutan dari tahapan sebelumnya pada tahap ini peneliti melakukan tindakan nyata melakukan proses pembelajaran berhadapan langsung dengan peserta didik kelas VI mempedomani Langkah-langkah 
pembelajaran sesuai dengan skenario yang telah dipersiapkan sebelumnya.

Tindakan siklus I dilakukan sebanyak dua kali pertemuan masingmasing berlangsung selama 3 x 45 menit pelajaran, pertemuan pertama pada tanggal 09 September 2019 dan pertemuan kedua pada tanggal 23 september 2019. Kegiatan pada siklus I diakhiri dengan pemberian tes formatif yang terdiri dari 10 pertanyaan meliputi tujuh berjenis pilihan ganda dan tiga berjenis esay

\section{Pengamatan (Observing)}

Tahapan pengamatan dan atau observasi dilakukan bersamaan dengan pelaksanaan pembelajaran pada prosesnya peneliti dibantu dua orang kolaborator penelitian yang telah disepakati sebelumnya yaitu satu orang kepala sekolah SDN 51/IX Setiris Muaro Jambi dan satu orang guru senior SDN 51/IX Setiris Muaro Jambi, masingmasing kolaborator bertindak menjadi pengamat/ observer yang bertugas merekam kegiatan pembelajaran melalui lembar observasi sesuai dengan apa yang terjadi selama proses pembelajaran berlangsung. Hasil belajar peserta didik siklus I dapat dilihat pada tabel 4.
Tabel 4. Hasil belajar peserta didik siklus I

\begin{tabular}{|c|c|c|c|c|}
\hline \multirow[b]{2}{*}{ Siklus } & \multicolumn{3}{|c|}{ Hasil Belajar } & \multirow{2}{*}{$\begin{array}{c}\text { Ketuntasan } \\
\text { Klasikal } \\
(\%)\end{array}$} \\
\hline & $\begin{array}{c}\text { Nilai } \\
\text { Terendah }\end{array}$ & $\begin{array}{c}\text { Nilai } \\
\text { Tertinggi }\end{array}$ & $\begin{array}{l}\text { Rata2 } \\
\text { Skor }\end{array}$ & \\
\hline Pra & 60 & 73 & 65,57 & $18 \%$ \\
\hline I & 68 & 78 & 73,21 & $64 \%$ \\
\hline
\end{tabular}

Berdasarkan hasil belajar sebagaimana terlihat pada Tabel 4 diketahui adanya peningkatan hasil belajar peserta didik secara signifikan ketuntasan klasikal yang semula 18\% meningkat menjadi $64 \%$ pada siklus I. Kendatipun hasil menunjukkan peningkatan namun belum mencapai ketuntasan klasikal 100\% sebagaimana yang ditetapkan sekolah, dengan kata lain masih terdapat $36 \%$ peserta didik belum tuntas atau terdapat 14 peserta didik yang tuntas sedangkan sisahnya delapan peserta didik belum tuntas. Hasil tersebut menjadi kajian pada tahap refleksi siklus I.

Sedangkan penjaringan data melalui observasi aktivitas guru mununjukkan skor sebesar $70 \%$ kategori Cukup, item yang dominan yaitu manajemen waktu, sedangkan tiga item lainnya dianggap perlu mendapatkan perhatian lebih diantaranya menyampaikan materi pelajaran yang dikorelasikan dengan aktivitas keseharian/ menyampaikan langkahlangkah dan metode pelajaran dengan 
model CTL; menjelaskan materi yang dianggap sulit dikaitkan dengan aktivitas keseharian peserta didik; dan item mendorong peserta didik mengaitkan situasi/ keadaan di dunia nyata dengan pelajaran yang tengah berlangsung. Selanjutnya penjaringan observasi kegiatan peserta didik menunjukkan sebesar 65\% kategori Cukup, item yang dominan yaitu mendengarkan/ memperhatikan penjelasan guru, sedangkan lima item lainnya dianggap perlu mendapatkan perhatian lebih untuk dijadikan bahan pengkajian pada tahap refleksi siklus 1 diantaranya: kegigihan bertanya tentang pelajaran yang dihubungkan dengan aktivitas sehari hari peserta didik; antusias merespon pelajaran yang berkaitan dengan aktivitas keseharian peserta didik; memberikan contoh kongkrit aktivitas sehari-hari peserta didik yang berhubungan dan pelajaran; menyimpulkan dan merangkum pelajaran; mengerjakan tes formatif.

\section{Refleksi (Reflecting)}

Pada tahap ini peneliti bersama kolaborator penelitian melakukan pertemuan dengan tujuan melakukan refleksi hasil yang didapat dari pelaksanaan Tindakan siklus I dengan memperhatikan hasil lembar observasi dan hasil ketuntasan belajar peserta didik serta hal-hal yang dianggap perlu dibicarakan serta penetapan tindak lanjut tindakan.

Kajian pertama ketuntasan belajar peserta didik siklus I menunjukkan peningkatan dari kondisi hasil sebelumnya yaitu dari $18 \%$ ketuntasan klasikal yang dicapai pada pra siklus meningkat menjadi $64 \%$ pada siklus I dengan kategori Cukup, kendatipun pelaksanaan siklus I meunjukkan peningkatan hasil namun belum mencapai kriteria keberhasilan klasikal $100 \%$ dengan skor individu sebesar $\geq 73$, dengan demikian penelitian dilanjut siklus II dengan menempuh tahapan yang cenderung sama yaitu rencana, Tindakan, pengamatan dan refleksi namun dengan memerhatikan hal-hal yang direvisi.

Kajian kedua yaitu hasil observasi aktivitas guru siklus I menunjukkan persentase skor sebesar 70 atau dalam kategori Cukup, hal-hal yang perlu direvisi dan diperbaiki untuk dilakukan Kembali pada siklus II diantaranya: (1) Menyampaikan materi pelajaran yang dikorelasikan dengan aktivitas keseharian/ menyampaikan langkahlangkah dan metode pelajaran dengan model CTL perlu ditingkatkan lagi 
dengan menampilkan contoh-contoh kongkrit dengan mempertimbangkan kompleksitas keseharian peserta didik; (2) Menjelaskan materi yang dianggap sulit dikaitkan dengan aktivitas keseharian peserta didik perlu ditingkatkan dengan penguasaan terhadap ciri khas model CTL dan penambahan pembendaharaan pengalaman yang nantinya akan ditampilkan kepada peserta didik; (3) Mendorong peserta didik mengaitkan situasi/ keadaan di dunia nyata dengan pelajaran yang tengah berlangsung perlu ditingkatkan, dalam penyelenggaraan model CTL ternyata tidak cukup hanya memaparkan model-model sesuai Langkah-langkah yang dilakukan, kemampuan guru dalam mendorong peserta didik untuk siap menerima pelajaran baru merupakan hal penting lainnya, karenanya pada siklus II perlu ditingkatkan dengan memaksimalkan perlibatan masing-masing peserta didik dalam kegiatan di dalam kelompok masing-masing yang berujung pada rasa percaya diri untuk mendiseminasikan hasil kerja ditengah kelompok lainnya.

Kajian ketiga yaitu hasil penjaringan lembar observasi kegiatan peserta didik siklus I yang menunjukkan skor sebesar 65 kategori Cukup, hasil tersebut mengindikasikan bahwa diperlukannya revisi atas lima item untuk dilakukan kembali pada siklus II diantaranya: kegigihan bertanya tentang pelajaran yang dihubungkan dengan aktivitas sehari hari peserta didik perlu mendapatkan perhatian lebih dengan cara mendorong rasa ingin tahu peserta didik; antusias merespon pelajaran yang berkaitan dengan aktivitas keseharian peserta didik perlu ditingkatkan dengan cara lebih memahami karakteristik peserta didik dengan berbagai keunggulan dan kelemahannya; memberikan contoh kongkrit aktivitas sehari-hari peserta didik yang berhubungan dengan pelajaran perlu diperkuat lagi dengan cara menciptakan ciri khas model CTL dengan mempedomani Langkah-langkahnya dan kesiapan dalam menggunakanya; menyimpulkan dan merangkum pelajaran perlu direvisi dengan cara memberikan peluang dan kesempatan yang sama dalam mengeksplorasi realitas keseharian dengan reinforcement dan stimulus yang tepat; mengerjakan tes formatif perlu direvisi agar pada siklus berikutnya, fenomena mengganggu teman, tidak dapat berkonsentrasi dengan baik, dan sibuk dengan aktivitas sendiri tidak terulang kembali. 


\section{Siklus II}

Pelaksanaan siklus II merupakan lanjutan dari tahapan refleksi siklus I dengan melakukan tahapan yang cenderung sama pada siklus I yaitu perencanaan, Tindakan, pengamatan dan refleksi, pelaksanaan siklus II mempedomani uraian revisi pada siklus I. pelaksanaan siklus II dilakukan dua pertemuan pertama pada tanggal 07 oktober 2019 dan pertemuan kedua 14 oktober 2019. Hasil belajar siklus II dapat dilihat pada tabel 5 .

Tabel 5. Hasil belajar peserta didik Siklus II

\begin{tabular}{|c|c|c|c|c|}
\hline \multirow[b]{2}{*}{ Siklus } & \multicolumn{3}{|c|}{ Hasil Belajar } & \multirow{2}{*}{$\begin{array}{c}\text { Ketuntasan } \\
\text { Klasikal } \\
(\%)\end{array}$} \\
\hline & $\begin{array}{c}\text { Nilai } \\
\text { Terendah }\end{array}$ & $\begin{array}{c}\text { Nilai } \\
\text { Tertinggi }\end{array}$ & $\begin{array}{l}\text { Rata2 } \\
\text { Skor }\end{array}$ & \\
\hline I & 68 & 78 & 73,21 & $64 \%$ \\
\hline II & 73 & 84 & 79,71 & $100 \%$ \\
\hline
\end{tabular}

Berdasarkan hasil belajar peserta didik siklus II sebagaimana terlihat pada Tabel 5 terlihat mengalami peningkatan dengan signifikan, nilai terandah yang tadinya 68 pada siklus I meningkat menjadi 73 , nilai tertinggi yang semula 78 pada siklus I meningkat menjadi 84 pada siklus II rata-rata skor yang semula 73,21 meningkat menjadi 79,71 pada siklus II, ketuntasan klasikal semula 64\% pada siklus I meningkat menjadi $100 \%$ pada siklus II. Hasil yang didapat dari pelaksanaan siklus II mengindikasikan bahwa ketuntasan belajar peserta didik sebagaimana yang dikehendaki sekolah sudah tercapai dengan kata lain seluruh peserta didik kelas VI sudah mencapai KKM $\geq 73$. Hasil tersebut menjadi bahan kajian pada tahap refleksi siklus II untuk menentukan tindak lanjut tindakan.

Selanjutnya hasil observasi aktivitas guru menunjukkan skor sebesar $88 \%$, kendatipun masih terdapat lima item yang belum mendapatkan skor maksimum namun aktivitas guru sudah dinyatakan berhasil karena skor $88 \%$ berada pada kategori Tinggi, hasil observasi kegiatan peserta didik menunjukkan sebesar 85\%, kendatipun hasil observasi menunjukkan masih terdapat enam item yang belum memperoleh skor maksimum namun perolehan skor $85 \%$ diinterpretasikan kategori tinggi.

\section{Refleksi siklus II}

Setelah melihat hasil yang diperoleh dari pelaksanaan siklus II menunjukkan bahwa ketuntasan belajar secara klasikal yang semula $64 \%$ pada siklus I meningkat menjadi $100 \%$ pada siklus II dengan nilai tertinggi 84 dan nilai terendah 73 , ketercapaian tersebut sesuai dengan KKM sekolah yang menetapkan $100 \%$ tuntas secara klasikal 
dengan KKM sebesar $\geq 73$ secara individu.

Hasil yang diperoleh dari pengamatan aktivitas guru siklus II juga menunjukkan peningkatan dengan signifikan, skor yang tadinya $70 \%$ atau berada pada rentang interpretasi Cukup meningkat menjadi $88 \%$ atau berada pada rentang interpretasi Tinggi, begitupula dengan hasil yang diperoleh dari pengamatan kegiatan peserta didik siklus II menunjukkan peningkatan skor yang tadinya diperoleh $65 \%$ pada siklus I atau berada pada rentang interprasi Cukup meningkat menjadi $85 \%$ pada siklus II atau berada pada interpretasi Tinggi.

Dengan perolehan yang didapat dari pelaksanaan siklus II, menunjukkan bahwa kriteria keberhasilan dalam penelitian ini sudah tercapai dengan kata lain model pembelajaran CTL terbukti dapat meningkatkan hasil belajar peserta didik, keberhasilan tersebut selaras dengan pernyataan Johnson (2014:182) menyatakan bahwa manusia dianugerahi Nurani oleh Maha Pencipta untuk senantiasa membina keingintahuan yang berujung pada pemaknaan berbagai fenomena maka model CTL hadir di tengah kebutuhan yang memungkinkan berhasil diterapkan karena memiliki penyesuaian yang amat dekat dengan kebiasaan peserta didik. Kebiasaan yang dimaksud merupakan aktivitas yang cenderung dilakukan peserta didik sebagai anggota keluarga, anggota masyarakat dan masyarakat sekolah. Pernyataan yang tidak jauh berbeda juga dikemukakan oleh Rosalin, E (2015:127) menyatakan bahwa penerapan model CTL cenderung akan berhasil karena peserta didik didorong untuk terlibat langsung atas pengalaman yang dilakukannya dalam kegiatan sehari hari. Setelah dilakukannya tahapan refleksi siklus II dengan memerhatikan temuan hasil bahwa secara keseluruhana/ klasikal peserta didik sudah mencapai $K K M \geq 73$ yang juga menjadi kriteria keberhasilan dalam penelitian ini maka, dengan demikian penelitian diakhiri pada siklus II.

\section{SIMPULAN}

Berdasarkan hasil penelitian dan pembahasannya dapat disimpulkan bahwa melalui model pembelajaran Contextual Teaching and Learning (CTL) dapat meningkatkan hasil belajar IPA sub tema tumbuhan sumber kehidupan peserta didik kelas VI SDN 51/IX Setiris Muaro Jambi, Hal tersebut dapat dilihat dari peningkatan hasil 
belajar peserta didik dari pelaksanaan siklus I, dan siklus II. Saran yang dapat peneliti berikan diantaranya: Bagi sekolah, hasil penelitian dapat dijadikan referensi untuk meningkatkan mutu dan kualitas Pendidikan sekolah; Bagi guru menjadi alternatif solusi dalam memecahkan isu-isu rendahnya hasil belajar peserta didik khususnya pelajaran IPA kelas VI sub-tema tumbuhan sumber kehidupan; Bagi Peneliti, menjadi referensi dan bahan perbandingan mengadakan penelitian sejenis dan penelitian lanjutan

\section{DAFTAR PUSTAKA}

Arsip, N. 2019. Nilai Harian IPA Kelas VI. Arsip.

Daryanto. 2018. Penelitian Tindakan Kelas dan Penelitian Tindakan Sekolah. Yogyakarta: GAVA MEDIA.

Hamdi, M. 2018. Penelitian Tindakan Sekolah (PTS) Teaori dan Praksis dalam Pendidikan . Jambi: UNJA Press.

Johnson, E. B. 2014. Contextual Teaching \& Learning Menjadikan Kegiatan Belajar Mengajar Mengasikkan dan Bermakna. Bandung: MLC.

Kemdikbud. 2015. Buku Tematik Terpadu Kurikulum 2013 Tema 7 Kepemimpinan (Buku Guru SD/MI Kelas VI). Jakarta: Pusat Kurikulum dan Pembukuan, Balitbang, Kemdikbud.
Kemdikbud. 2015. Buku Tematik Terpadu Kurikulum 2013 Tema 7 Kepemimpinan (Buku Siswa SD/MI Kelas VI). Jakarta: Pusat Kurikum dan Pembukuan, Balitbang, Kemdikbud.

Permendikbud No 53 Tahun 2015 Tentang Penilaian Hasil Belajar.

Rosalin, E. 2015. Gagasan Merancang Pembelajaran Kontekstual. Bandung: PT Karsa Mandiri Persada.

Sofiah. 2018. Model CTL untuk Meningkatkan Hasil Belajar Pelajaran IPA Kelas II SDN 111/IX Muhajirin. Jurnal SINEKTIK, Volume 1(no 1), Juni $\mathrm{p}: 13-25$.

Taniredja, T., Faridli, M., \& Harmianto, S. 2017. Model-model Pembelajaran Inovatif dan Efektif. Bandung: Alfabeta.

Wulandari, L. A., \& Koesdyantho, A. R. 2018. Upaya Meningkatkan Ranah Afektif Peserta Didik dalam Pembelajaran Pendidikan Karakter. Journal SINEKTIK, Volume 1(no 1), 165-177. 